\title{
Comparative study of primary productivity in Yamuna River canal of different parts of Yamunanagar Haryana, India
}

\author{
Reetu Kamboj ${ }^{1}$, Nikhill, Manvinder ${ }^{1}$, Nishan ${ }^{1}$, Harpreet Kaur²*, Babita Malik², and \\ Shivani Sood ${ }^{3}$ \\ ${ }^{1}$ Department of Biotechnology, Mukand Lal National College, Yamunanagar-135001, India \\ ${ }^{2}$ Department of Zoology, Mukand Lal National College, Yamunanagar-135001, India \\ ${ }^{3}$ Department of Biotechnology, MMU Mullana, Ambala-133001, India
}

\begin{abstract}
The present study discusses the primary productivity in the middle course of Yamuna River canal in Yamunanagar of Haryana, India by investigating different physico-chemical parameters like $\mathrm{pH}$, temperature, TDS and DO with the help of water testing kit. The light and dark bottle technique was used to measure primary production. For estimating the primary productivity, various physico-chemical parameters is to be analysed and its study play a vital role in interpreting the health of aquatic water body. Three sampling locations were established along the course of the river at the average distance of $15 \mathrm{kms}$. starting from Dadupur head then at Yamuna Nagar and at last Radaur in March, 2015. Wide variations were observed in Temperature (15.9-16.8 $\left.{ }^{\circ} \mathrm{C}\right), \mathrm{pH}(7.98-8.14)$, TDS (143-173 ppm), Dissolved Oxygen (7.64-8.56 mg/l), GPP (107.81-170.31 $\mathrm{mgCm}^{-3}$ water.hour ${ }^{-1}$ ), NPP (25.31-120.42 $\mathrm{mgC} \mathrm{m}^{-3}$ water.hour $\left.{ }^{-1}\right)$. The overall average values for the GPP and NPP in Yamuna River canal, based on the data of all the three stations were $142.46 \mathrm{mgC} \mathrm{m}^{-3}$ water.hour ${ }^{-1} \mathrm{GPP}$ \& $55.59 \mathrm{mgC} \mathrm{m}^{-3}$ water.hour ${ }^{-1} \mathrm{NPP}$. The main focus of the study was to estimate the Net Primary Productivity in Yamuna River canal at various regions for analysing the water quality and find the pollution level due to increased anthropogenic activities in the region as the canal water utilizes for drinking, irrigation, industrial and several domestic purposes.
\end{abstract}

KEY WORDS: PRIMARY PRODUCTIVITY, GROSS PRIMARY PRODUCTIVITY, NET PRIMARY PRODUCTIVITY, COMMUNITY RESPIRATION

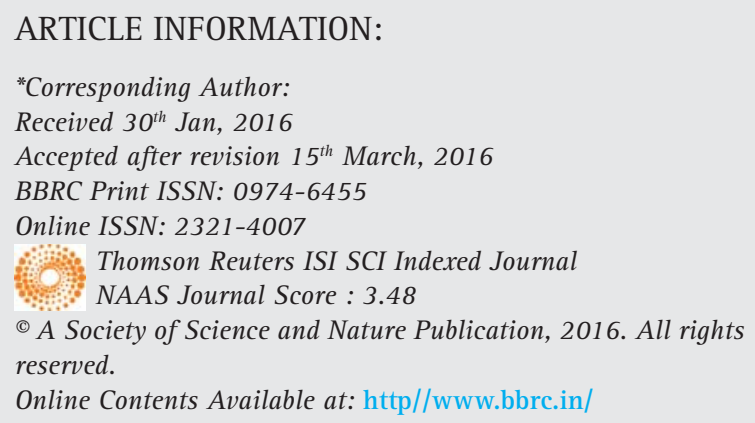




\section{INTRODUCTION}

Haryana, unlike its neighbouring states, have no web of rivers. Ghagger, Saraswati, Markanda, Tangri and Yamuna are the main rivers flowing through the state, out of which Yamuna is perennial (Vats et al., 2011). The most essential and prime necessity for performing life supporting activities is water (Gupta et al., 2013). The most important freshwater resource is rivers on which most of the developmental activities like agriculture, industry, transportation, aquaculture, public water supply, etc. are dependent. Deterioration of the river water quality on large scale is due to huge loads of waste from industries, domestic sewage and agricultural practices (Khaiwal et al., 2003). The water quality can be indicated and described by its physical, chemical and microbial characteristics (Dhembare et al., 1997). Also it can be used to detect the effects of pollution on the water quality (Sujitha et al., 2012). From the Ecological point of view to assess the quality of water, the important prime consideration is the analysis of physicochemical water parameters which tells the best usage of water for drinking, bathing, irrigation, fishing, industrial processing and other domestic purposes (Shinde and Nagre 2015). Any alteration in the physico-chemical characteristics of water adversely influences and disturbs the water quality which had a great impact on aquatic life (Malviya and Dwivedi 2015).

In aquatic ecosystems, autotrophs (algae, planktons, etc.) act as primary producers on which all the life forms depends (Ogbaugu et al., 2011). To sustain a level of growth and respiration and to support a biological population, primary productivity is to be estimated (Bishnoi et al., 2013).The basis of ecosystem functioning is the biological production of autotrophs which is manipulated by primary productivity of a water body (Mohanty et al., 2014; Odum et al., 1971). There is a main role of primary productivity in providing energy and organic matters to the entire biological community (Ahmed et al., 2005). Light (solar energy) and nutrients are the main limiting factors to primary production in an aquatic ecosystem (Guildford and Hecky 2000; Simmons et al., 2004), though distribution of phytoplankton (algae) are also affected by temperature and seasonal variations in light intensity (Vaillancourt et al., 2003). Therefore, present studies have been undertaken to evaluate the water quality of Yamuna River canal in Yamunanagar District at three locations in terms of physicochemical characteristics. An attempt has also been made to calculate numerical values of primary productivity to compare the water quality of Yamuna River canal at different location.

\section{MATERIALS AND METHODS}

The samples for the present study were collected from the middle course of Yamuna River canal of Yamunanagar district of Haryana, India. Three sampling locations were established along the course of the river at the average distance of $15 \mathrm{kms}$, starting from Dadupur head then at Yamuna Nagar and at last Radaur in March, 2015.

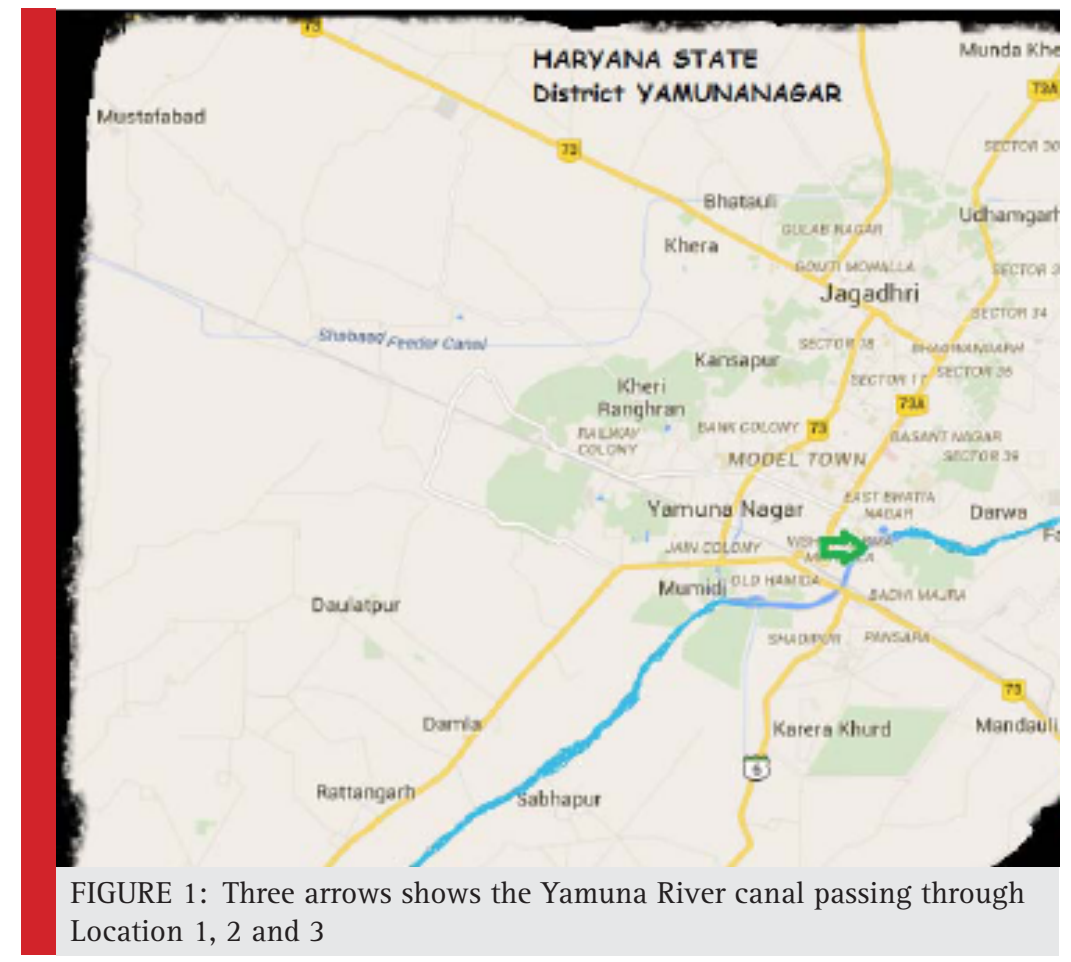




\section{TOPOGRAPHY}

Yamunanagar lies in latitude $30^{\circ} 5$ North and longitude $77^{\circ} 15^{\prime}$ East. The district is bounded by the Yamuna River canal and across it by the Saharanpur district of Uttar Pradesh in the south east, Karnal district in south, Punjab in the north-west and Shivalik hills in the north-east (Vats et al. 2011). Total geographical area of the district is 1756 sq.km and comprises 4\% of total area of Haryana State. Yamunanagar District is divided into one sub-division and six-development blocks viz. Bilaspur, Chachrauli, Jagadhri, Mustafabad, Radaur and Sadhaura. Atmospheric temperature ranges from between $6^{\circ} \mathrm{C}$ (January) to $49^{\circ} \mathrm{C}$ (May, June) and humidity could reach as high as $90 \%$, usually during the wet season. The major activity of inhabitants of the area is farming, though some also engage in fishing and sand mining in this river.

\begin{tabular}{|c|c|c|c|}
\hline Sr. No. & $\begin{array}{l}\text { Sampling } \\
\text { Locations }\end{array}$ & Latitude & Longitude \\
\hline 1. & $\begin{array}{l}\text { Dadupur Head } \\
\text { (location 1) }\end{array}$ & $30^{\circ} 20^{\prime}$ & $77^{\circ} 38^{\prime}$ \\
\hline 2. & $\begin{array}{l}\text { Yamuna Nagar } \\
\text { (location 2) }\end{array}$ & $30^{\circ} 12^{\prime}$ & $77^{\circ} 29^{\prime}$ \\
\hline 3. & Radaur (location 3) & $30^{\circ} 03^{\prime}$ & $77^{\circ} 17^{\prime}$ \\
\hline
\end{tabular}

\section{PHYSICO-CHEMICAL ANALYSIS}

Various physico-chemical parameters like Temperature, $\mathrm{pH}$, Total Dissolved Solids (TDS) and Dissolved Oxygen (D0) were determined to study primary productivity using Water Testing Kit by following standard methods (Rain and Thatcher 1990; Rao et al., 1993; Clescerl et al., 1993; Pelczer et al., 1986; Jain and Jain 2007). A thermometer and $\mathrm{pH}$ meter was used to determine Temperature and $\mathrm{pH}$ of the water samples on the spot. DO was determined by BOD bottle method. Community Respiration (CR), Gross Primary Productivity (GPP) and Net
Primary Productivity (NPP) were calculated by using the values of different parameters analyzed using the following formulas given in the Table 2 .

Table 2: Formulas for calculating Gross Primary Productivity (GPP), Community Respiration (CR) and Net Primary Productivity (NPP) (Sreenivasan 1964)

\begin{tabular}{|ll|}
\hline Parameters & Formulas \\
\hline Gross Primary & GPP $(\mathrm{mg}$ C m-3 water \\
Productivity (GPP) & $\mathrm{hr}-1)=(375)^{*}(\mathrm{LB}-\mathrm{DB}) /$ \\
& $\mathrm{PQ}{ }^{* T}$ \\
Community & $\mathrm{CR}(\mathrm{mg} \mathrm{C} \mathrm{m-3}$ water $\mathrm{hr}-1)$ \\
Respiration (CR) & $=(375)^{*}(\mathrm{LB}-\mathrm{IB})^{*}(\mathrm{RQ}) / \mathrm{T}$ \\
Net Primary & $\mathrm{NPP}(\mathrm{mg} \mathrm{C} \mathrm{m-3} \mathrm{water}$ \\
Productivity (NPP) & $\mathrm{hr}-1)=\mathrm{GPP}-\mathrm{CR}$ \\
\hline
\end{tabular}

\section{RESULTS}

The experimental data of physico-chemical parameters in the middle course of Yamuna River canal at different locations had been observed and noted at two different depths for the estimation of primary productivity in the river water to illustrate the water quality and study the influence of industrial effluents putting into the River.

\section{TEMPERATURE}

The highest and lowest temperature range of Yamuna River canal water sample as compared to location 2 is of location 3 and location 1 respectively shown in Figure 2.

\section{ESTIMATION OF PH}

The highest and lowest $\mathrm{pH}$ range of Yamuna River canal water sample as compared to location 2 is of location 1 and location 3 respectively. There is variation in the $\mathrm{pH}$ of water sample at different locations when measured at different depth shown in Figure 3.

\begin{tabular}{|llll|}
\hline \multicolumn{3}{l}{ Table 3: Physico-chemical characteristics and primary production of Yamuna } \\
River canal at 3 sampling locations. \\
\hline Parameter & Location 1 & Location 2 & Location 3 \\
Temperature $\left({ }^{\circ} \mathrm{C}\right)$ & $15.9 \pm 0.1$ & $16.2 \pm 0.1$ & $16.8 \pm 0.1$ \\
pH & $8.15 \pm 0.02$ & $8.02 \pm 0.02$ & $7.99 \pm 0.02$ \\
TDS (ppm) & $145 \pm 3.0$ & $162 \pm 3.0$ & $173 \pm 3.0$ \\
DO (mg/l) & 8.55 & 8.12 & 7.64 \\
GPP (mg C m-3 water.hr-1) & 157.8 & 137.55 & 132.03 \\
CR (mg C m-3 water.hr-1) & 115.31 & 46.87 & 98.87 \\
NPP (mgC.m-3water.hr-1) & 42.49 & 90.68 & 33.59 \\
\hline
\end{tabular}




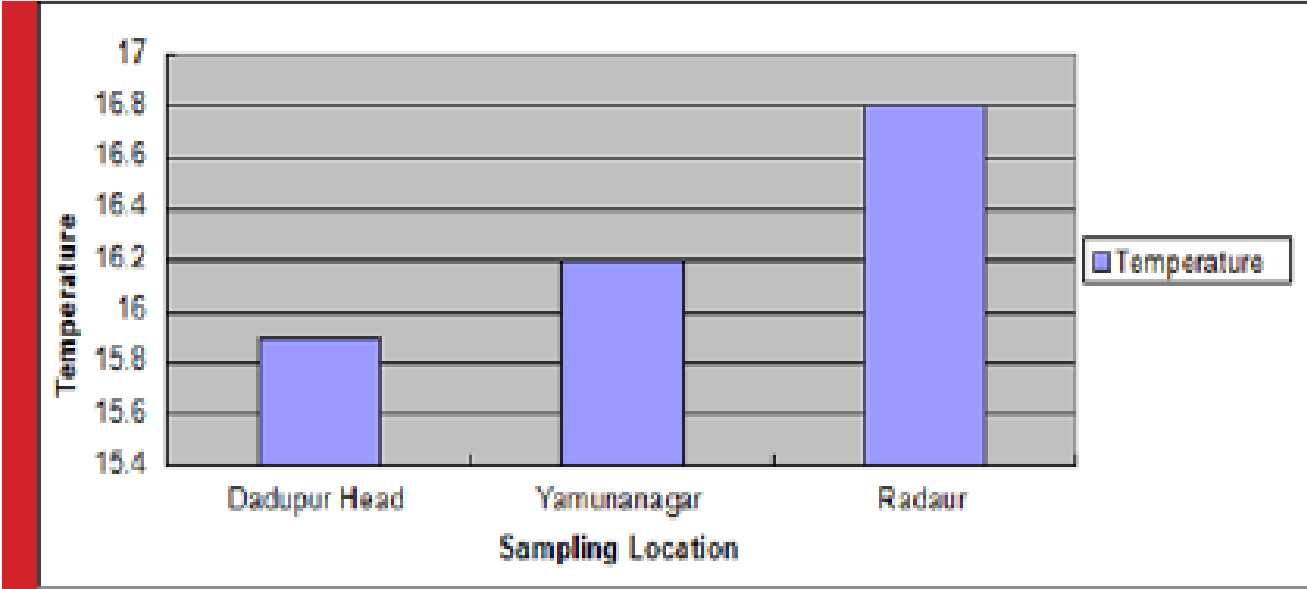

FIGURE 2: Variation in Temperature (oC) at three sampling locations

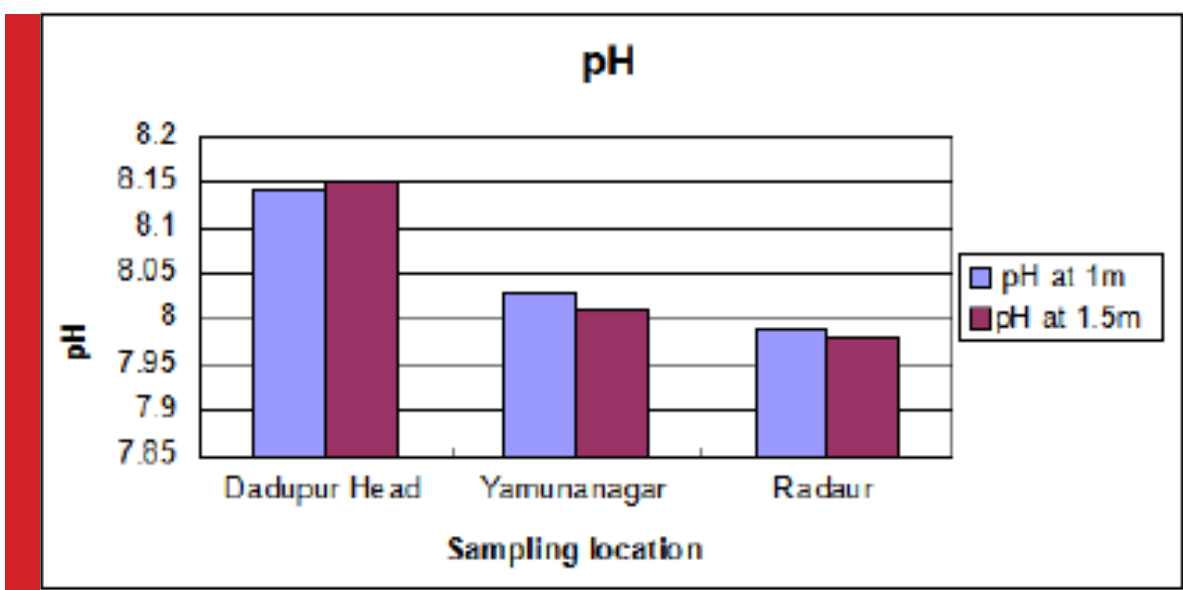

FIGURE 3: Variation in $\mathrm{pH}$ at three sampling locations

\section{TOTAL DISSOLVED SOLIDS}

The highest and lowest value of TDS of Yamuna River canal water sample compared to location 2 is of location 3and location 1 respectively. There is variation in the TDS of water sample at different locations when measured at different depth shown in Figure 4.

\section{DISSOLVED OXYGEN}

The highest and lowest value of DO of Yamuna River canal water sample compared to location 2 is of location 1 and location 3 respectively. There is variation in the D0 of water sample at different locations when measured at different depth shown in Figure 5.

\section{GROSS PRIMARY PRODUCTIVITY}

The highest and lowest value of GPP of Yamuna River canal water sample as compared to location 2 is of loca- tion 1 and 3 respectively. There is variation in the GPP of water sample at different locations when measured at different depths shown in Figure 6.

\section{COMMUNITY RESPIRATION}

The highest and lowest CR range of Yamuna River canal water sample as compared to location 2 is of location 1 and location 3 respectively. There is variation in the CR of water sample at different locations when measured at different depths shown in Figure 7.

\section{NET PRIMARY PRODUCTIVITY (NPP)}

The lowest value of GPP of Yamuna River canal water sample as compared to location 2 is of location 3.Location 2 has maximum value of $\mathrm{CR}$. There is variation in the GPP of water sample at different locations when measured at different depths shown in Figure 8. 


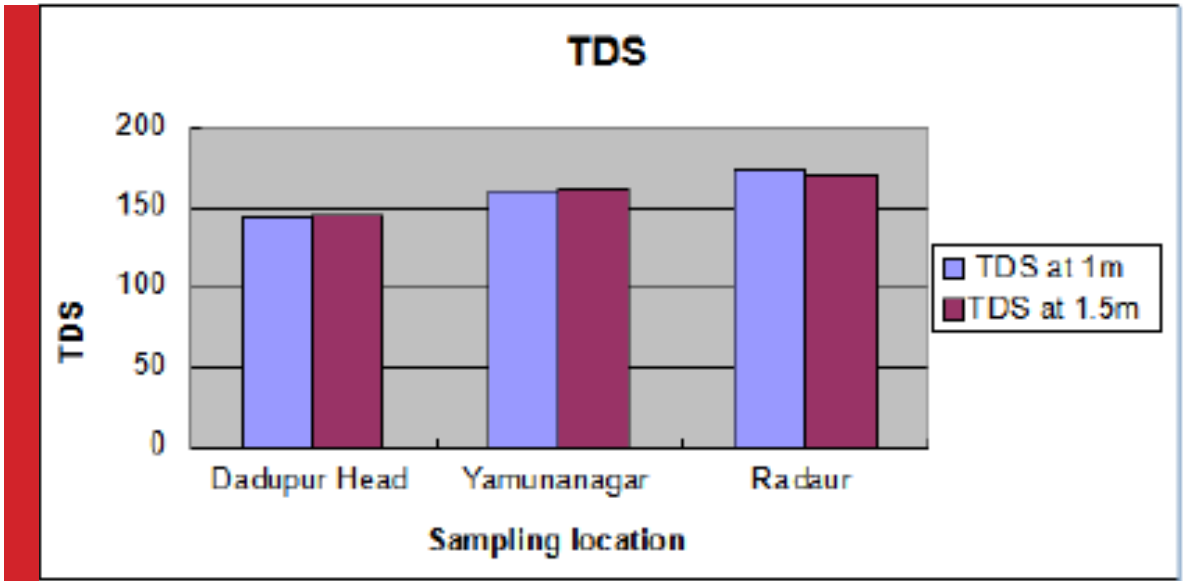

FIGURE 4: Variation in Total Dissolved Solids (ppm) at three sampling locations

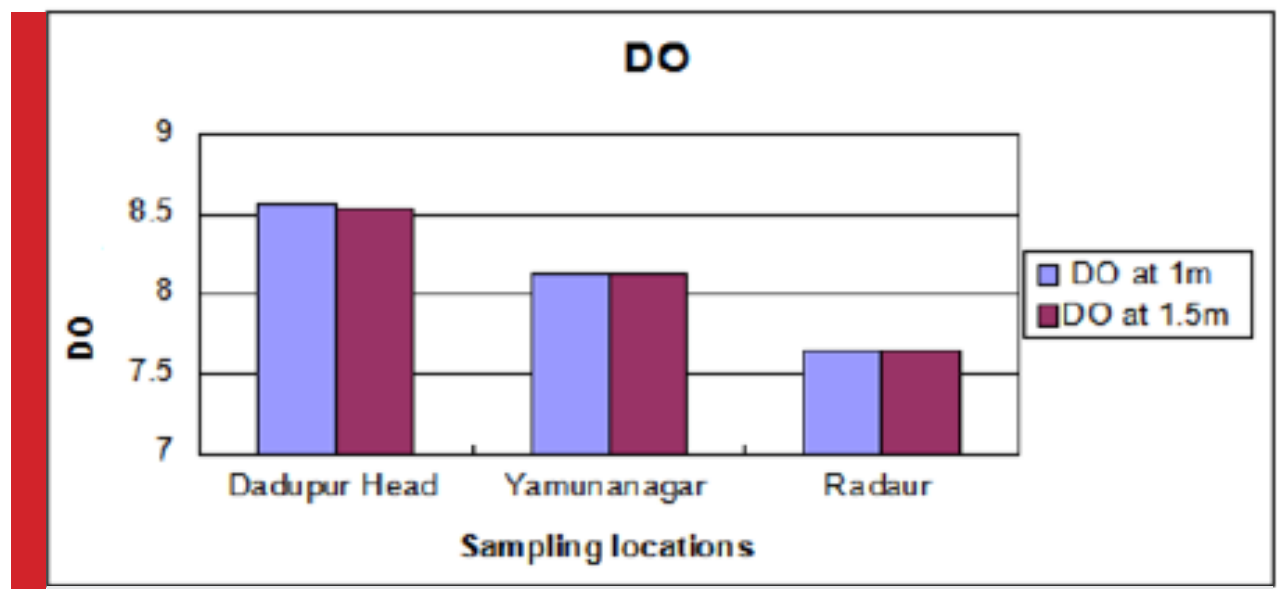

FIGURE 5: Variation in Dissolved Oxygen (mg/l) at three sampling locations

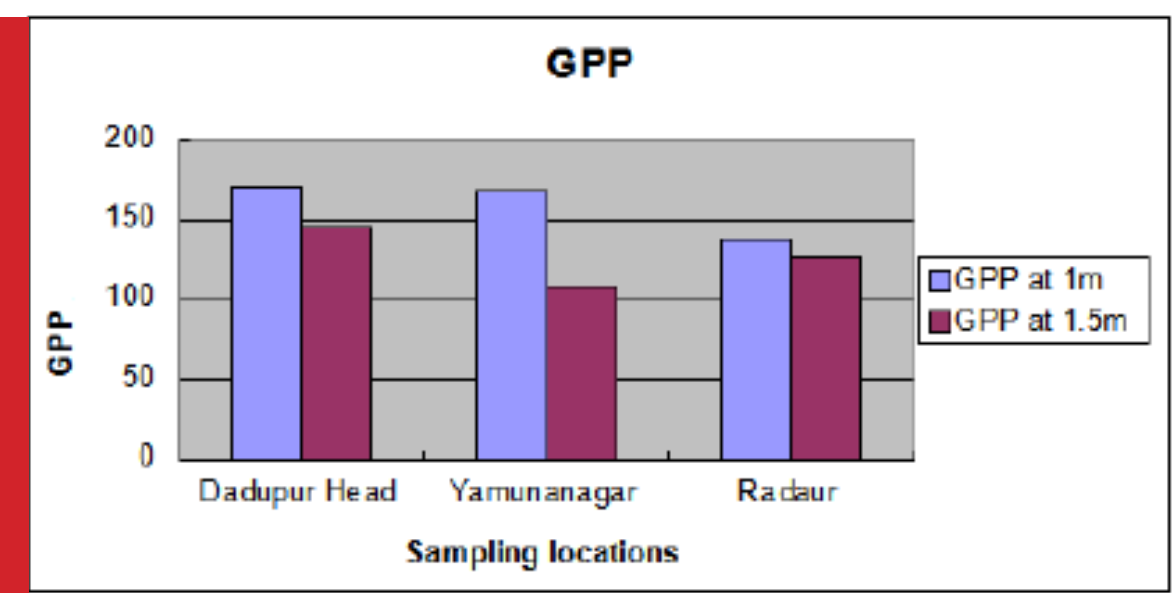

FIGURE 6: Variation in Gross Primary Productivity $\left(\mathrm{mg} \mathrm{C} \mathrm{m}^{-3}\right.$ water $\left.\mathrm{hr}^{-1}\right)$ at three sampling locations 


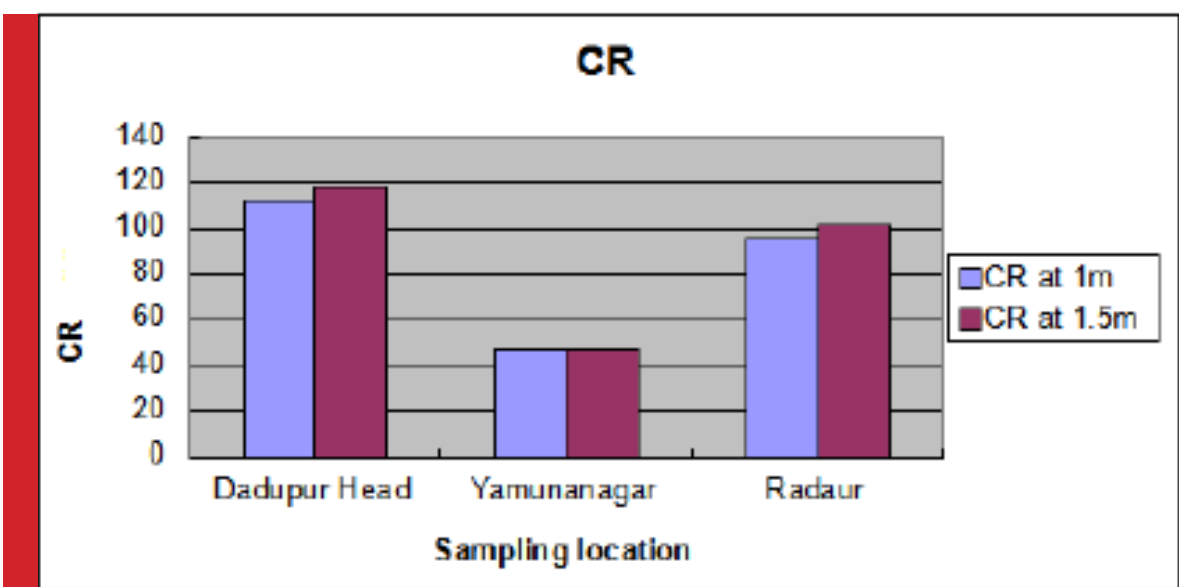

FIGURE 7: Variation in Community Respiration $\left(\mathrm{mg} \mathrm{C} \mathrm{m}^{-3}\right.$ water $\left.\mathrm{hr}^{-1}\right)$ at three sampling locations

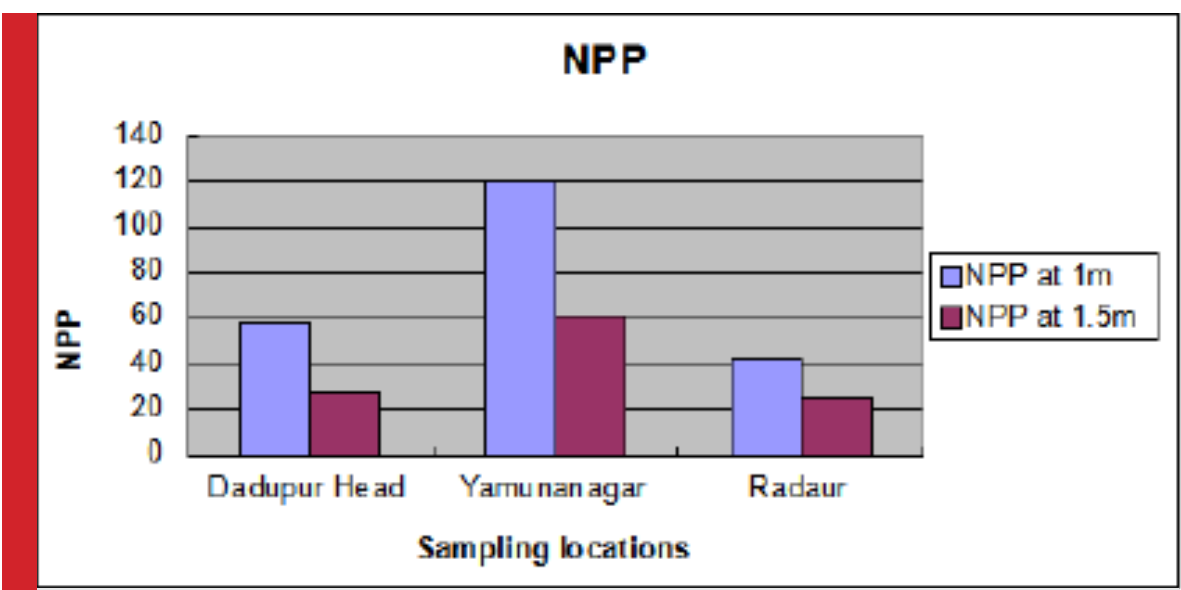

FIGURE 8: Variation in Net Primary Productivity $\left(\mathrm{mg} \mathrm{C} \mathrm{m}^{-3}\right.$ water $\left.\mathrm{hr}^{-1}\right)$ at three sampling locations

\section{DISCUSSION}

The industrial waste and domestic sewage affects the overall condition of the Yamuna canal water which is depicted by decrease in DO, increase in BOD, high ammonia, nitrite and low values of water quality indices (WQI) (Bhatnagar et al., 2009). Very low D0 and high Total Dissolved Solids (TDS), which were found to be important parameters for detecting river water quality illustrated the polluted water of Delhi downstream stretch and better quality of Delhi upstream stretch (Khaiwal et al., 2003) High amount of organic matter under going biological degradation is the reason for the depletion of D0 in water (Rim-Rukeh et al., 2006). Temperature play an important role in influencing the $\mathrm{pH}$, alkalinity and DO concentration in the water and lowering of $\mathrm{pH}$ in Delhi downstream is because of greater input of waste from different type of industries and sewage of Delhi.
Flow of water in and out of an organism's cell (osmosis) can be determined by calculating the density Total Dissolved

Solids which is essential for the maintenance of aquatic life (Shinde and Nadre 2015). Physiological stress to fishes, phytoplankton and zooplankton is due to increased temperature, which not only reduced oxygen availability, but also increases oxygen demand (Desai 1995; Sharma and Selvaraj 2000). The high primary productivity promoting factor is considered to be alkaline $\mathrm{pH}$ (Khaiwal et al., 2003). Low nutrient levels and high turbidity seems to be due to low productivity (Ogbuagu and Ayoade 2011). The decrease of oxygen in the dark bottles helps in determination of respiration rate which is given as their carbon equivalents (Rajyalakshmi et al., 1975). Water quality of Yamuna is affected by the wastes from the industries, agricultural runoff and the drains carrying municipal sewage of the cities as the industrial belt of Haryana is 
mainly situated along the north- eastern part of the state along the Yamuna. According to the Central Pollution Control Board (CPCB, 2000), untreated sewage is responsible for $70 \%$ of the pollution in rivers which results in low D0 and high BOD (Khaiwal et al., 2003). According to the present study, location 2 seems to have the highest Net primary Productivity which is depicted by the lowest value of Community Respiration when observed under alkaline $\mathrm{pH}(8.02)$, temperature $\left(16.2^{\circ} \mathrm{C}\right)$, TDS (162 ppm) and DO $(8.12 \mathrm{mg} / \mathrm{l})$ when compared with the location 1 and 3. Low Net Primary Productivity at Location 1 and 3 may be due to the addition of high amount of industrial wastes. Moreover domestic waste is added in high amount to Yamuna River canal located at location 1 and 3 as these are situated near rural area.

\section{CONCLUSION}

According to the physico-chemical parameters of Yamuna River canal it is concluded that NPP of different sampling location shows wide range of variations as follows:

\section{Yamuna Nagar $>$ Dadupur Head $>$ Radaur}

The highest primary productivity is found to be at Yamunanagar as compared to Dadupur Head and Radaur. This indicates that planktonic activity is greatest in Yamunanagar. This low productivity could be attributed to the observed low nutrient levels because of industrial effluents and high TDS (which exerts influences on photosynthetic activities of the autotrophs). Ongoing commercial sand mining in the river must have led to the depletion of nutrient stores, especially in the Benthal regions of the aquatic system. Due to addition of various products in river water the physiochemical characteristics of water changes. Industrial waste water drains are directly connected to the river \& heavy metal pollution are occurred. The river pollution directly affect on the ecology, variation in the biotic factors. Therefore the present study deals with the water quality of Yamuna River canal and comparison was done to show the effect of industrial effluents and other anthropogenic activities. From the above results and discussions, we concluded that it is necessary to treat the water of Yamuna River canal and to establish efficient treatment plants by the effluents generating industries for maintaining the important parameters within the permissible limit prescribed by world health organization/Indian council of medical Research.

\section{REFERENCES}

Ahmed, K.K.U., S.V. Ahmed, G.C. Halder, M.R.A. Hossainand and T.S. Ahmed. (2005). Primary production and fish yield estimation in the Meghana river system, Bangladesh. Asian Fisheries Science Vol. 18: 95-105.
Bhatnagar, A., G. Chopra and P. Malhotra. (2009). Water quality indices and abiotic characteristics of western Yamuna canal in Yamunanagar, Haryana. Journal of Applied and Natural Science Vol. 1 Issue 2: 149-154.

Bishnoi, R.K., B.K. Sharma, V.S. Durve and L.L.Sharma. (2013). Primary Productivity in elation to Planktonic Biodiversity in a Stretch of Gang Canal (Rajasthan). Universal Journal of Environmental Research and Technology Vol. 3 Issue 2: 266-272.

Clescerl, L.S., A.E. Greenberg and A.D. Eaton. (1993). Standard Methods of Examination of Water and Waste Water. 18th Ed, American Public Health Association, USA. 2340.

Desai P.V. (1995). Water quality of Dudhsagar river of Dudhsagar (Goa), India Poll Res. Vol. 14 Issue 4: 377-382.

Dhembare, A.J. and G.M. Pondhe. (1997). Correlation of ground water parameters of Pravara area. Maharashtra state, India Vol. 12: 32-33.

Guildford, S.J.,and R. E.Hecky. (2000). Total nitrogen. Total phosphorus, and nutrient limitation in lakes and oceans: Is there a common relationship? Limnology and Oceanography Vol. 45: 1213-1223.

Gupta, N., K.K. Yadav, V. Kumar and D.Singh. (2013). Assessment of Physicochemical Properties of Yamuna River canal in Agra City. International Journal of Chem Tech Research CODEN (USA) Vol. 5 Issue 1: 528-531.

Jain, P.C. and M. Jain. (2007). Engineering Chemistry. 15th Edn., Dhanpat Rai Publishing Company Pvt. Ltd., New Delhi, India.

Khaiwal, R., Ameena, Meenakshi, Monika, Rani and A. Kaushik. (2003). Seasonal variations in physico-chemical characteristics of river Yamuna in Haryana and its ecological best designated use. Journal of Environmental Monitoring. Vol. 5: 419-426.

Malviya, P., and A.K. Dwivedi. (2015). Physico-chemical parameters of Narmada River Water: A review. International Journal of Chemical Studies. Vol. 3 Issue 2: 01-04.

Mandal, B., S. Some and B. Banerjee. Comparative studies on primary productivity of sewage fed freshwater fishpond in relation to production efficiency of phytoplankton.

Mohanty, S.S., D.S. Pramanik and B.P. Dash. (2014). Primary Productivity of Bay of Bengal at Chandipur in Odisha, India. International Journal of Scientific and Research Publications Vol. 4 Issue 10: 1-6.

Odum, E.P. (1971). Fundamentals of Ecology, 3rd Ed. W.B. Saunders Company, Philadelphia. 574.

Ogbuagua, D.H., and A.A. Ayoade. (2011). Estimation of primary production along gradients of the middle course of Imo River in Etche, Nigeria. International Journal of Biosciences Vol. 1 Issue 4: 68-73.

Pelczer, M.J., R.D. Reid, E.C.S. Chem and N.R. Kreig. (1986). Microbiology. 5th Ed., McGraw Hill Publication, New Delhi, India.

Rain, F.H. and L.L. Thatcher. (1990). Methods for Collection and Analysis of Water Samples. U.S. Government Printing Of1ice, Washigton, DC., USA. 
Rajyalakshmi, T., and T.V. Premswarup. (1975). Primary productivity in river Godavari India. Indian Journal of Fisheries Vol. 22(1-2): 205-214.

Rao, C.S. (1993). Environmental Pollution Control Engineering. John Wiley and Sons, New York, USA. ISBN-13: 9780470217634. 431.

Rim-Rukeh, A., O.G. Ikhifa, A.P. Okokoyo. (2006). Effects of agricultural activities on the water quality of Orogodo river, Agbor Nigeria. Journal of applied sciences research Vol. 2 Issue 5: 256-259.

Sharma M.S. and N. Selvaraj. (2000). Heavy metal toxicity of freshwater zooplankton in relation to temperature variations. Poll Res. Vol. 19 Issue 1: 159-163.

Shinde, N.G., and S.S. Nagre. (2015). Evaluation of Physicochemical Parameters of Godavari River From Kopargaon Tahasil, Dist-Ahmednagar, India. Indian Journal of Applied Research. Vol. 5 Issue 9: 315-316.

Sreenivasan, A. (1964) Energy transformation through primary productivity and fish production in some tropi- cal freshwater impoundments and ponds. In: Z. Kajak and A. Hillbricht-Ilkowska (Editors), Productivity Problems in Freshwaters. Polish Scientific Publishers, Warsaw 505514.

Simmons, J.A., J.M. Long, J.M. Ray. (2004). What limits the productivity of acid mine drainage treatment ponds? Mine Water and the Environment Vol. 23: 44-53.

Sujitha, P.C., D. Mitra Dev, P.K. Sowmya and R. Mini Priya. (2012). Physico-chemical parameters of Karamana river water in Trivandrum district, Kerala, India. International Journal Of Environmental Sciences Vol. 2 Issue 3: 14171434.

Vaillancourt, R.D., J. Marra and R. T. Barber Jr. WO. (2003). Primary productivity and in situ quantum yields in the Ross Sea and Pacific Sector of the Antarctic Circumpolar Current. Deep-Sea Res. Vol. 11 Issue 50: 559-578.

Vats, R., and S.K. Gupta. (2011). Icthyofauna of Four District of Northern Haryana. Journal of Arts, Science \& Commerce Vol. 2 Issue 4: 23-29. 